\title{
Cultivation of Juvenile Fat Snook (Centropomus parallelus Poey, 1860) Fed Probiotic in Laboratory Conditions
}

\author{
Moysés Cavichioli Barbosa ${ }^{1}$, Adolfo Jatobá ${ }^{2,3^{*}}$, Felipe do Nascimento Vieira ${ }^{2}$, Bruno \\ Corrêa Silva $^{2}$, José Luiz Pedreira Mourino ${ }^{2}$, Edemar Roberto Andreatta ${ }^{2}$, Walter Quadros \\ Seiffert $^{2}$ and Vinícius Ronzani Cerqueira ${ }^{1}$ \\ ${ }^{1}$ Laboratório de Piscicultura Marinha; Departamento de Aqüicultura; Universidade Federal de Santa Catarina; \\ 88061-600; Florianópolis - SC - Brasil. ${ }^{2}$ Laboratório de Camarões Marinhos; Departamento de Aqüicultura; \\ 88062-601; Universidade Federal de Santa Catarina; Florianópolis - SC - Brasil. ${ }^{3}$ Instituto Federal Catarinense; \\ Rodovia BR-280 - km 27; 89245-000; Araquari - SC - Brasil
}

\begin{abstract}
The objective of this study was to investigate the growth of juvenile fat snook (Centropomus parallelus) in laboratory conditions when fed a diet supplemented with the probiotic Lactobacillus plantarum. Changes in the intestinal flora, haematological parameters and growth performance were assessed using 180 fishes $(54.2 \pm 13.4 \mathrm{~g}$ each). The fishes were subjected to two treatments divided into six cages: 1) feed supplemented with probiotic, and 2) feed without probiotic (control). The temperature, dissolved oxygen and salinity were maintained at $25 \pm 1{ }^{\circ} \mathrm{C}, 4.0 \mathrm{mg} . \mathrm{L}^{-1}$ and 33 $\%$, respectively. After 10 weeks of culture, the fishes fed probiotic had reduced viable culturable heterotrophic bacteria and Vibrio spp. and increased lactic acid bacteria in the intestinal tract, as well as a higher number of thrombocytes, leukocytes and lymphocytes in the blood. No significant difference was observed in the growth, survival or body composition, but the hepatosomatic index was significantly higher in the fishes fed with probiotic and control.
\end{abstract}

Key words: Lactobacillus plantarum, hematology, bacterial microbiota, body index

\section{INTRODUCTION}

The Brazilian coast has several marine fishes species with potential for aquaculture, including the Fat Snook ( $C$. paralellus), because it is euryhaline and can be cultured in marine and estuarine environments, endure low temperatures $\left(10{ }^{\circ} \mathrm{C}\right.$ lethal temperature) and dissolved oxygen concentrations (1 mg. $\left.\mathrm{L}^{-1}\right)$. This fish found throughout the Brazilian coast, was more abundant in the north and northeast (Cerqueira, 2004).
Fat snook are of great interest for the commercial and sport fishing and are used to restock the coastal lagoons (Cerqueira, 2004). Their production in large-scale is constrained by the difficulty of producing large quantities of juveniles due to the high mortality rates in this stage (Hjelm et al., 2004; Temple et al., 2004).

Bacterial diseases are commonly associated with aquaculture production. Some causative agents include bacteria from Vibrios, Aeromonas, Pseudomonas, Streptococcus and other genera

*Author for correspondence: adjatoba@yahoo.com.br 
(Austin and Austin, 2007). In marine fish farming, bacterial disease is recorded on eggs, larvae, juveniles and adults, and the development of diseases results from the interaction of pathogen, host and environment (Toranzo et al., 2005). Dixon (1991) correlated the bacterial diseases in the fishes with minor problems such as stress, temperature changes, salinity, water quality, parasites and chemotherapy treatments. To control the bacterial diseases, antibiotics are commonly used, but the inappropriate use of chemotherapy may lead to the selection of some resistant pathogenic bacterial strains (Vázquez et al., 2005), and also be a source of environmental pollution (Boyd and Massaut, 1999).

Probiotics may be a viable alternative to prevent the bacterial disease in aquaculture (Jatobá et al., 2008a). They can act in preventing the disease through reducing the bacterial load by competitive exclusion or production of inhibitory substances, and can also stimulate the host animal's immune system and produce additional digestive enzymes (Verschuere et al., 2000). Gatesoupe (1999) defined the probiotics for aquaculture as the microbial cells added in such a way that they entered the digestive tract of animals while still alive, with the aim of improving the health of the animal.

The use of Lactobacillus showed good results in fish culture. Souza (2007) observed a probiotic effect of $L$. plantarum and Lactococcus sp. in vitro and in vivo for fat snook, which enhanced the activity of an alkaline protease that could help the digestive activities of the fish. Jatobá et al. (2008a and 2008b) confirmed the probiotic effect of $L$. plantarum on Nile tilapia in fresh and brackish water.

The objective of this study was to assess the changes in intestinal flora, haematological parameters and growth performance of juvenile fat snook in laboratory conditions when fed a diet supplemented with probiotic (L. plantarum).

\section{MATERIALS AND METHODS}

The experiments used 180 fat snook (Centropomus parallelus) juveniles, weighing $54.2 \pm 13.4 \mathrm{~g}$ and with a total length of $18.3 \pm 1.6 \mathrm{~cm}$. The probiotic bacteria used was Lactobacillus plantarum strain (CPQBA 227-08 DRM), which was molecularly identified in the Centro Pluridisciplinar de Pesquisa Químicas, Biológicas e Agrárias da
Universidade Estadual de Campinas. This strain was isolated from the intestinal tract of tilapia, and approved by in vitro and in vivo tests (Jatobá et al., 2008a).Six cages $\left(3.4 \mathrm{~m}^{3}, 2 \mathrm{~m}\right.$ x $\left.1.7 \mathrm{~m} \mathrm{x} 1 \mathrm{~m}\right)$ were used in two fibreglass circular ponds (6 m radius) with a capacity of $50 \mathrm{~m}^{3}$ and constant water renewal, four cages in one and two in the other. The experimental units were divided into two treatments with three replicates each, with a completely randomized design. The treatments were as follows: (1) fat shook fed a commercial diet supplemented with probiotics (L. plantarum), and, (2) fat shook fed a commercial diet without the probiotic, for 10 weeks.

The feed was prepared according to Jatobá (2008a). The culture of $L$. plantarum in MRS medium (De Man, Rogosa and Sharpe, 1960) was sprayed on commercial extruded diet (with $11.1 \%$ moisture, $18.6 \%$ ash, $10.5 \%$ total fat, $7.8 \%$ acid soluble fibre and $55.3 \%$ total protein) and incubated at $35^{\circ} \mathrm{C}$ for $24 \mathrm{~h}$ (Ramírez et al., 2006). The diet of the control treatment was sprayed only with sterile MRS culture medium. Five ten-fold serial dilutions were cultured in modified MRS Agar culture medium (Ramírez et al., 2006) to quantify the cells in the diet. This resulted in a count of $1 \times 10^{7}$ colony-forming units (CFU) of $L$. plantarum per gram.

The feed rate of $1.5 \%$ of biomass per day, adjusted after five weeks through biometrics, were used in $30 \%$ of the fishes in each experimental unit to do the biometrics. The feeding frequency was twice daily (8:00 and 14:00 h). At the end of the biometrics experiments, after a day of fasting, all the fishes were evaluated for growth and weight. The temperature, dissolved oxygen and salinity were maintained at $25 \pm 1^{\circ} \mathrm{C}, 4.0 \mathrm{mgL}^{-1}$ and 33 $\%$, respectively. To measure the water quality parameters (total ammonia, nitrite, phosphate and silicate), daily water samples from each experimental unit were collected using a plastic bottle $(250 \mathrm{~mL})$. The assays were carried out with a spectrophotometer $2 \mathrm{~K}$ SL microprocessor. The daily renewal rate in the water tanks was $100 \%$ a day.

The total dissolved ammonia was measured by the Solorzano (1969) method as modified by Strickland and Parsons (1972). The total dissolved phosphate was measured by the method of Murphy and Riley (1962) and silica by the second method of Mullin and Riley (1955). The methods used for the determination of phosphate and silicon were as described by Aminot and Chaussepied (1983). 
Water samples were collected every two weeks from two fibreglass circular ponds to measure the $\mathrm{pH}$, presence of lactic acid bacteria, orthophosphate and silicate. All the analysis were done in triplicate.

After 10 weeks, survival, specific growth rate $(\mathrm{SGR}=\{100 \times[$ (natural logarithm of final weight - natural logarithm of initial weight)/Number of days]), feed conversion rate and condition factor $\left(\mathrm{CF}=\right.$ body weight/Standard Length $\left.{ }^{3} \times 100\right)$ were measured. Liver, gonads, viscera and peritoneal fat were removed from five fishes of each experimental unit to calculate the following indices: hepatosomatic $=$ (liver weight $/$ total weight $) \quad \mathrm{x} 100$, gonadosomatic $=($ gonad weight/total weight) $\mathrm{x} 100$, viscerosomatic $=$ (viscera weight/weight) $\times 100$ and liposomal $=$ (peritoneal fat weight/total weight) $\mathrm{x} 100$. The analysis of final body composition (the five dissected fishes of each replicate) were carried out as detailed by the Association of Official Analytical Chemists (AOAC, 1999). The dry matter was obtained by drying at $105{ }^{\circ} \mathrm{C}$ (gravimetric method), mineral matter (ash) by incineration in a muffle for five hours, fat by ether extraction after acid hydrolysis and the crude protein by acid digestion. The samples were homogenized prior to analysis.

At the end of the experiment, the intestinal tracts of a group of three fishes per experimental unit were dissected for the microbiological evaluations. After $24 \mathrm{~h}$ without feed, the gut tracts were macerated and serially diluted ten-fold in sterile $0.65 \%$ saline solution. Samples of each dilution were cultured on tryptone soy agar (TSA), thiosulfate citrate bile sucrose (TCBS) agar and MRS, and incubated for $48 \mathrm{~h}$ at $30{ }^{\circ} \mathrm{C}$ for viable culturable heterotrophic bacterial counts, Vibrionaceas and lactic acid bacteria, respectively. Five fishes per experimental unit $(15$ per treatment) were anaesthetized with benzocaine (50 mg. $\mathrm{L}^{-1}$ ) and approximately $1.0 \mathrm{~mL}$ of blood was drawn from the caudal vein of each fish for the preparation of blood smears in duplicate. Blood slides were stained with Giemsa/May-Grunwald stain (Rosenfeld, 1947) for differential leukocyte count and total count of thrombocytes and leukocytes by the indirect method (Martins et al., 2004). A blood aliquot was used for the determination of the hematocrit (Goldenfarb et al., 1971). The remainder was stored in glass containers on ice for total erythrocyte count in a hemocytometer. Only the microbiological data were transformed to $\log _{(x+1)}$. All data were evaluated by $\mathrm{t}$-test at $5 \%$ level of significance.

\section{RESULTS}

The $\mathrm{pH}$, total ammonia $\left(\mathrm{NH}_{4}{ }^{+}, \mathrm{NH}_{3}\right)$, toxic ammonia $\left(\mathrm{N}-\mathrm{NH}_{3}\right)$, orthophosphate $\left(\mathrm{P}-\mathrm{PO}_{4}\right)$ and silicate $\left(\mathrm{SiO}_{3}\right)$ were $7.6 \pm 0.1,0.49 \pm 0.23 \mathrm{mg} . \mathrm{L}^{-1}$, $0,01 \pm 0.01 \mathrm{mg} . \mathrm{L}^{-1}, 0.01 \pm 0.03 \mathrm{mg} . \mathrm{L}^{-1}$ and $0.39 \pm$ $0.11 \mathrm{mg} . \mathrm{L}^{-1}$, respectively. There were no significant differences in the growth, survival, feed conversion rate and specific growth rate between treatments (Table 1). Among the body indices, only the hepatosomatic index showed a significant difference (Table 2). The body composition of the fishes did not differ between the treatments (Table 2). The hematocrit percentage, erythrocytes, monocytes and neutrophils did not change between the treatments (Table 3), but fat snook fed the probiotic diet showed a higher number of thrombocytes, total leukocytes and circulating lymphocytes (Table 3).

The gut tracts of the fishes fed the diet supplemented with probiotic had reduced viable culturable heterotrophic bacteria and Vibrio spp. as well as increased acid lactic bacteria (Fig. 1).

Table 1 - Survival, final weight and length, specific growth rate, feed rate and condition factor (mean \pm standard deviation) of fat snook (Centropomus parallelus) fed a probiotic (Lactobacillus plantarum) and control diet.

\begin{tabular}{lcc}
\hline \multirow{2}{*}{ Indices } & \multicolumn{2}{c}{ Treatment } \\
\cline { 2 - 3 } & Control & Probiotic \\
\hline Survival $(\%)$ & $90,00 \pm 8,82$ & $91,11 \pm 5,09$ \\
Final weight $(\mathrm{g})$ & $71,02 \pm 18,72$ & $74,12 \pm 16,20$ \\
Final length $(\mathrm{cm})$ & $19,45 \pm 1,66$ & $19,63 \pm 1,32$ \\
Specific growth rate $\left(\%\right.$. day $\left.^{-1}\right)$ & $0,33 \pm 0,00$ & $0,37 \pm 0,05$ \\
Feed rate & $0,89 \pm 0,19$ & $1,11 \pm 0,08$ \\
Condition factor & $0,97 \pm 0,04$ & $0,98 \pm 0,04$ \\
\hline
\end{tabular}

Different letters indicate significant differences $(\mathrm{p}<0.05)$ in $\mathrm{t}$-test between treatments. 
Table 2 - Biochemical composition and body indices (mean \pm standard deviation) of fat snook (Centropomus parallelus) fed a probiotic (Lactobacillus plantarum) and control diet.

\begin{tabular}{ccc}
\hline Body índices (\%) & \multicolumn{2}{c}{ Treatment } \\
\cline { 2 - 3 } Probiotic \\
\hline Hepatossomatic índex & $1,15 \pm 0,20^{\mathrm{a}}$ & $1,35 \pm 0,25^{\mathrm{b}}$ \\
Gonadossomatic índex & $0,11 \pm 0,06$ & $0,10 \pm 0,04$ \\
Viscerossomatic índex & $2,24 \pm 0,29$ & $2,11 \pm 0,32$ \\
Lipossomal index & $3,86 \pm 1,40$ & $4,13 \pm 1,68$ \\
\hline Body biochemical composition (\%) & $67,28 \pm 1,80$ \\
*Ash & $67,26 \pm 1,02$ & $17,52 \pm 1,64$ \\
*Total fat & $16,73 \pm 1,73$ & $20,95 \pm 6,09$ \\
*Total protein & $19,49 \pm 3,20$ & $59,02 \pm 2,03$ \\
\hline
\end{tabular}

*Dry matter; different letters indicate significant differences $(\mathrm{p}<0.05)$ in t-test between treatments.

Table 3 - Haematological parameters (mean \pm standard deviation) of fat snook (Centropomus parallelus) fed a probiotic (Lactobacillus plantarum) and control diet.

\begin{tabular}{ccc}
\hline Hematological parameters & \multicolumn{2}{c}{ Treatments } \\
\cline { 2 - 3 } & Control & Probiotic \\
Hematocrit $(\%)$ & $33,9 \pm 5,1$ & $34,2 \pm 5,0$ \\
Erythrocyte $\left(\times 10^{6} \mu \mathrm{L}^{-1}\right)$ & $2,2 \pm 0,4$ & $2,9 \pm 0,1$ \\
Thrombocyte $\left(\times 10^{3} \mu \mathrm{L}^{-1}\right)$ & $6,8 \pm 1,7^{\mathrm{a}}$ & $12,6 \pm 1,3^{\mathrm{b}}$ \\
Leukocyte $\left(\times 10^{3} \mu \mathrm{L}^{-1}\right)$ & $39,3 \pm 4,9^{\mathrm{a}}$ & $55,0 \pm 9,0^{\mathrm{b}}$ \\
Lymphocyte $\left(\times 10^{3} \mu \mathrm{L}^{-1}\right)$ & $35,5 \pm 5,6^{\mathrm{a}}$ & $50,3 \pm 5,6^{\mathrm{b}}$ \\
Neutrophil $\left(\mathrm{x} 10^{3} \mu \mathrm{L}^{-1}\right)$ & $2,3 \pm 2,6$ & $2,4 \pm 1,7$ \\
Monocyte $\left(\mathrm{x} 10^{3} \mu \mathrm{L}^{-1}\right)$ & $1,4 \pm 0,5$ & $2,3 \pm 0,5$ \\
\hline
\end{tabular}

Different letters indicate significant differences $(\mathrm{p}<0.05)$ in t-test between treatments.

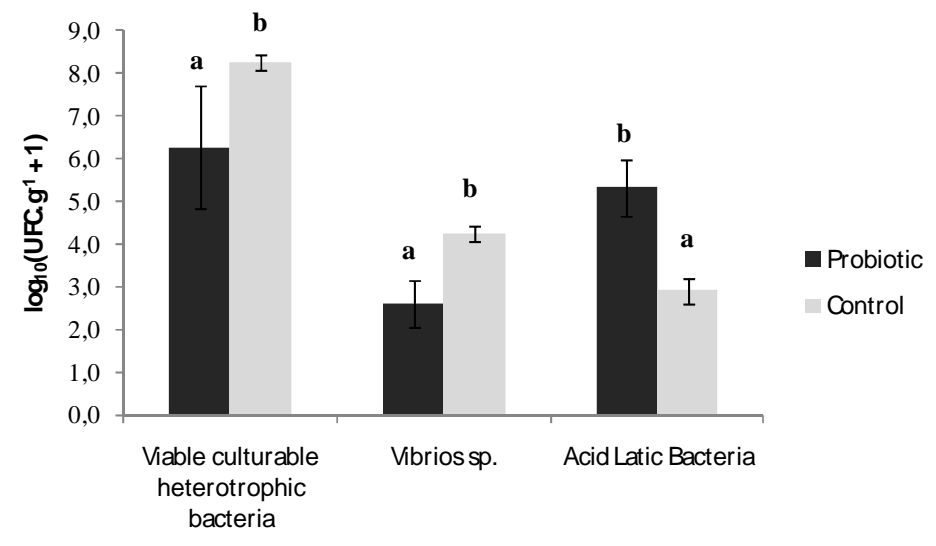

Figure 1 - Bacterial counts in the gut of fat snook (mean \pm standard deviation) of fat snook (Centropomus parallelus) fed a probiotic (Lactobacillus plantarum) and control diet. Different letters indicate significant differences $(\mathrm{p}<0.05)$ in t-test between treatments $\log \left(\right.$ ufc. $\left.g^{-1}+1\right)$.

\section{DISCUSSION}

Gildberg et al. (1995), using Lactobacillus sp. in juvenile Atlantic salmon (Salmo salar) and Hidalgo et al. (2006), using Bacillus cereus and B. toyoi in Dentex (Dentex dentex) did not show improved body indices, similar to what was seen in this work. Rengpipat et al. (2008) reported a beneficial effect on the growth and survival of
Asian juvenile snook (Lates calcarifer) using Lactobacillus sp. Carnevali et al. (2006), using $L$. delbrueckii delbrueckii isolated from the European sea bass (Dicentrarchus labrax), reported an increase in weight gain in the fishes fed on a diet with probiotics; this result was related to the specificity between the probiotic bacteria and host fish, as well as increased expression of the gene for the growth. 
The probiotic bacteria used in this study were assessed in a polyculture system with tilapia (Oreochromis niloticus) and marine shrimp (Litopenaeus vannamei). Following 12 weeks of growth, the feed efficiency, productivity and final weight increased $13.6 \%, 7.5 \%$ and $7.1 \%$, respectively in tilapia fed the probiotic diet (Jatobá, 2008a). The absence of differences in the indices evaluated in this work could be related to the diet offered or the lack of specificity between the bacteria and host (fish).

After 10 weeks, fishes gained an average of $20 \mathrm{~g}$ in both the treatments ( $0.5 \mathrm{~g}$ per week). Moreover, there was no difference in specific growth rate between the treatments (Table 1). Both were less than the results reported by Souza-Filho and Cerqueira, (2003). This suggested that the diet used did not meet the nutritional requirements for fat snook and/or laboratory conditions did not favour the fish growth. Laidley et al. (1988) found that any change in the hepatosomatic index could result from fat accumulation, a metabolism disorder or an increase in gluconeogenesis induced by a possible stress. The increase in the hepatosomatic index in the fishes treated with probiotic diet might be related to the lack of specificity between the probiotic ( $L$. plantarum isolated from Nile tilapia) and host (fat snook), which might have caused some change in the fish metabolism. The lipid accumulation might be associated with lipase production from lactic acid bacteria, even in small quantities (Fryer et al., 1976). Dentex juveniles (Dentex dentex) fed a wet diet supplemented with $B$. toyoi and B. cereus in different concentrations showed a difference between the probiotic and control treatments in body composition (Hidalgo et. al., 2006). In contrast, the body composition of the fat snook did not differ between the treatments in this work (Table 3).

Ramírez et al. (2006) and Gatesoupe (2008) related the reduction of gut tract bacteria with a probable mechanism of inhibition by competitive exclusion for the space and nutrients or by the change of microbial metabolism in the gut tract. In tilapia, this probiotic colonized easily in the laboratory and field, reducing viable culturable heterotrophic bacteria, Vibrio spp. and Pseudomonas spp and increasing the number of viable lactic acid bacteria in the gut tract (Jatobá et al., 2008a and 2008b). Carnevali et al. (2006) observed an increase in lactic acid bacteria in the gut tract of sea bass fed a diet supplemented with probiotic (L. delbrueckii delbrueckii).

The presence of lactic acid bacteria was not detected in the water; this could be explained by the high rate of daily renewal (100\% of the volume of water per day) and the possibility that the environment condition (water culture) might be inadequate to maintain live L. plantarum.

The hematocrit values were near those observed by Ranzani-Paiva et al. (2008) in fat snook inoculated with Saccharomyces cerevisiae. Welker et al. (2007), Aly et al. (2008) and Jatobá et al. (2008b) also reported no difference in the hematocrit between the probiotic and control treatments for tilapia fed a diet with probiotic. The thrombocytes in some species have roles in haemostasis, the defence mechanism, clotting and inflammation, and can also participate in the phagocytic activity during infection (Tavares-Dias, 2003). The high levels of thrombocytes suggest a better immune system in the fish treated with probiotics. The probiotic may have induced a higher production or release of lymphocytes and thrombocytes, which may be interesting, as these cells have important functions in the fish immune system (Secombes, 1996).

Changes in the numbers of neutrophils and monocytes in circulation are common in the fishes treated with probiotics when subjected to experimental infection (Aly et al., 2008; Kumar et al., 2008; Jatobá et al., 2008b). Having the same number of these cells ( $\mathrm{n}$ and $\mathrm{m}$ ) suggested that the probiotic did not activate the immune system, only made it more immunocompetent. This result was interesting, because the probiotic did not activate the immune system as an immunostimulant, and so did not waste the energy. This result suggested an improvement in response to infection, as was observed for Nile tilapia (Jatobá et al., 2008b).

\section{CONCLUSION}

The supplementation of L. plantarum in the diet of juvenile fat snook improved the bacterial microbiota in the gut tract and increased the number of thrombocytes, leukocytes and lymphocytes circulating in these fishes. The $L$. plantarum did not affect the growth, survival, feed conversion or body composition of fat snook fed with the probiotic diet. 


\section{ACKNOWLEDGMENTS}

This study was supported by CAPES. The authors would like to thank CNPq, Laboratório de Oceanografia Costeira (USFC) for carrying out the water analysis and Nicoluzzi Animal Ltda for the supply of the diet.

\section{REFERENCES}

Aly, S.M., Ahmed, W.A., Ghareeb, A.A., Mohamed, M.F. (2008) Studies on Bacillus subtilis and Lactobacillus acidophilus, as potential probiotics, on the immune response and resistance of Tilapia nilotica (Oreochromis niloticus) to challenge infections. Fish Shellfish Immun 25, 128-136.

Aminot, A., Chaussepied, M. (1983). Manuel dês Analyses Chimiques en Milieu Marin. CNEXO, Brest, 395 p.

Association of Official Analytical Chemists. Official Methods of Analyses. (1999) 16th ed. Association of Official Analytical Chemists, Arlington, VA, pp. 1298.

Austin, B., Austin, D.A. (2007) Bacterial fish pathogens: disease in farmed and wild fish, John Wiley and Sons, West Sussex, pp. 552.

Boyd, C.E., Massaut, L. (1999) Risks associated with the use of chemicals in pond aquaculture, Aquaculture 20, 13-132.

Carnevali, O., Vivo, L., Sulpizio, R., Gioacchini, G., Olivotto, I., Silvi, S., Cresci, A. (2006) Growth improvement by probiotic in European juveniles (Dicentrarchus labrax L.), with particular attention to IGF-1, myostatin and cortisol gene expression. Aquaculture 258, 430-438.

Cerqueira, V.R. (2004) Cultivo de peixes marinhos. In: Poli, C.R.; Poli, A.T.B; Andreatta, E.R., Beltrame, E., eds. Aqüicultura: Experiências Brasileiras. Florianópolis, SC:, Multitarefa. p.369-406.

De Man, J.C., Rogosa, M., Sharpe, M.E. (1960) A medium for the Cultivation of Lactobacilli, J Appl Bacteriol, 23, 30-135.

Dixon D.A. (1991) Antibiotic resistance of bacterial fish pathogens. In: Lavens P, Sorgeloos P, Jaspers E, Ollevier F. In: Larvi'91. Symposium on fish and crustacean. Aqua Eur Soc. Special Publication, 15, 184.

Fryer, T.F., Reiter, B. Lawrense, R.C. (1976) Lipolytic Activity of Lactic Acid Bacteria. J Dairy Sci, 50 (3), 388-389.

Gatesoupe, F.J. (2008) Updating the Importance of Lactic Acid Bacteria in Fish Farming: Natural Occurrence and Probiotic Treatments. J Mol Microb Biotech, 14, 107-114.

Gatesoupe F.J. (1999) The use of probiotics in aquaculture. Aquaculture, 180, 147-165.
Gildberg, A., Johansen, A., Bagward, J. (1995) Growth and survival of atlantic salmon (salmo salar) fry given diets supplemented with fish pretein hydrolysate and lactic acid bacteria during a challenge trial with Aeromonas salmonicida. Aquaculture, Amsterdam, 138, 23-34.

Goldenfarb, P.B., Bowyer, F.P., Hall, E., Brosius, E. (1971) Reproductibility in the hematology laboratory: the microhematocrit determination, Am J Clin Pathol, 56, 35-39.

Hidalgo, M.C., Skalli, A., Abellan, E., Arizcun, M., Cardenete, G. (2006) Dietary intake of probiotics and maslinic acid in juvenile dentex (Dentex dentex L.): effects on growth performance, survival and proteolytic activities. Aquacult nutr, 12, 256-266.

Hjelm, M., Bergh, O., Riazza, A., Nielsen, J., Melchiosen, J., Jensen, S., Duncan, H., Ahren, P., Birkbeck, H. (2004) Gram, L. Selection and identification of autochthonous potential probiotic bacteria from turbot larvae (Scophthalmus maximus) Rearing Units. Syst Appl Microbiol, 27, 360-371.

Jatobá, A., Vieira, F.N., Buglione, C.C., Silva, B.C., Mouriño, J.L.P., Jerônimo, G.T., Dotta, G., Martins M.L. (2008a) Utilização de bactérias ácido láticas isoladas do trato intestinal de tilápia-do-nilo como probiótico. Pesqui Agropecu Bras, 43, 1201-1207.

Jatobá, A. (2008b) Utilização de probiótico em sistema de policultivo de tilápias com camarões marinhos. Dissertação (Mestrado) - Universidade Federal de Santa Catarina, Florianópolis.

Kumar, R., Mukherjee, S.C., Ranjan, R., Nayak, S.K. (2008). Enhanced innate immune parameters in Labeo rohita (Ham.) following oral administration of Bacillus subtilis, Fish Shellfish Immun, 24, 168-172.

Laidley C.W., Woo, P.T.K., Leatherland, J.F. (1988) The stress-response of rainbow trout to experimental infection with the blood parasite Cryptobia salmositica Katz, 1951. J. Fish Bio, 32, 253-261

Martins, M.L., Pilarsky, F., Onaka, E.M., Nomura, D.T., Fenerick, Jr., Ribeiro, K., Myiazaki, D.M.Y., Castro, M.P., Malheiros, E.B. (2004) Hematologia e resposta inflamatória aguda em Oreochromis niloticus (Osteichthyes: Cichlidae) submetida aos estímulos único e consecutivo de estresse de captura. Boletim Instituto de Pesca, 30, 71-80.

Mullin, J.B., Riley, J.P. (1955) The spectrophotometric determination of nitrate in natural waters, with particular reference to sea-water, Anal Chim Acta, 12, 464-480.

Murphy, J., Riley, J.P. (1962) A modified single solution method for determination of phosphate in natural waters, Anal Chim Acta, 27, 31-36.

Ramírez, C., Bolívar, G.A., Ciffoni, G.A., Pancheniak, E.M.G., Soccol, E.F.R.C. (2006) Microorganismos lácticos probióticos para ser aplicados en la alimentación de larvas de camarón y peces como substituto de antibiótico, La Aliment Lat Am, 264, 7078. 
Ranzani-Paiva, M.J.T., Santos, A.A., Dias, C.D., Egami, R.M.S.I. (2008) Hematological and phagocytic response of the fat snook, Centropomus parallelus, reared in net cages, before and after inoculation with Sacharomyces ceresivisiae. Bioikos, 22 (1), 29-35.

Rengpipat, S., Rueangruklikhit, T., Piyatiratitivorakul, S. (2008) Evaluationn of lactic acid bacteria as probiotics for juvenile sea bass Lates calcarifer. Aquac Res, 39, 134-143.

Rosenfeld, G. (1947) corante pancrônico para a hematologia e citologia clínica: nova combinação dos componentes do May-Grünwald e do Giemsa num só controle de emprego rápido. Mem Instit But, 20, 32934.

Secombes, C.J., Hardie, L.J., Daniels, G. (1996). Citokines in fish: an update. Fish Shellfish Immun, 6, $329-34$.

Solorzano, L., Sharp, J.H. (1969) Determination of ammonia in natural waters by the phenylhypochlorite. Limnol Oceanogr, 14, 799-801.

Souza, R.M. (2007) Influência da aplicação de bactéria ácido lática na dieta sobre o cultivo de juvenis de Robalo Peva (Centropomus parallelus Poey, 1980). Dissertação (Mestrado) - Universidade Federal de Santa Catarina, Florianópolis. Souza-Filho, J.J., Cerqueira, V.R. (2003) Influência da densidade de estocagem no cultivo de juvenis de robalo-flecha mantidos em laboratório. Pesqui Agropecu Bras, 38 (11), 1317-1322.
Strickland, J.D.H., Parsons T.R. (1972) Fish Res. Board Can. Bull. In: A practical handbook of sea water analysis, Ottawa, Canada, pp. 122-311.

Tavares-Dias, M. Variáveis hematológicas de teleósteos brasileiros de importância zootécnica. (2003). Tese (Doutorado) - Universidade Estadual Paulista Jaboticabal.

Temple, S., Cerqueira, V.R., Brown , J.A. (2004) The effects of lowering prey density on the growth, survival and foraging behaviour of larval fat snook (Centropomus parallelus Poey 1860). Aquaculture, 233, 205-217.

Toranzo, A.E., Magariños, B., Romalde, J.L. (2005) A review of the main bacterial fish diseases in mariculture systems. Aquaculture, 246, 37- 61.

Vázquez, J.A., González, M.P., Murado, M.A. (2005) Effects of lactic acid bacteria cultures on pathogenic microbiota from fish. Aquaculture, 245, 149-161.

Verschuere, L., Rombaut, G., Sorgeloos, P., Verstraete, W. (2000) Probiotic bacteria as biological control agents in aquaculture. Microbiol Mol Biol R, 64, 655671.

Welker, T.L., Lim, C., Yildirim-Aksoy, M., Klesius, P.H. (2007) Growth, immune function, and disease and stress resistance of juvenile Nile tilapia (Oreochromis niloticus) fed graded levels of bovine lactoferrin. Aquaculture, 262, 156-162.

Received: September 15, 2010; Revised: November 24, 2010; Accepted: April 05, 2011. 